\title{
Determination of biologically active substances in protein-berry concentrates
}

\author{
Olena Grek, Olena Onopriichuk, \\ Tetiana Pshenychna, Alla Tymchuk
}

\author{
National University of Food Technologies, Kyiv, Ukraine
}

Keywords:

Protein

Berry

Coagulation

Polyphenols

Amino acid

Article history:

Received

20.06.2018

Received in revised form

29.08.2018

Accepted

30.11.2018

Corresponding

author:

E-mail:

DOI:

$10.24263 / 2310-$

$1008-2018-6-2-6$

\section{Abstract}

Introduction. Research of the polyphenolic compounds and amino acid composition of proteins, including the content of free and bound amino acids, in protein-berry concentrates (PBC), obtained by thermo acid coagulation are an actual direction.

Materials and methods. Protein-berry concentrates were obtained by thermo acid coagulation of milk proteins using blackcurrant paste as a coagulant, which is a source of biologically active substances - vitamins, minerals, polyphenols and others. Amino acid composition and polyphenolic compounds were determined by high performance liquid chromatography followed by the identification of individual compounds in the studied extracts of protein-berry concentrates.

Results and discussion. The research results of polyphenol composition were analyzed compared with the control (blackcurrant paste) and the degree of their transition to protein-berry concentrates was determined, which is about $55.31 \%$ of polyphenols, including anthocyanins.

Proteins in concentrates have a full amino acid composition and contain all essential amino acids, the content of which from amount is $41.97 \%$ and $43.96 \%$, respectively, for protein-berry and milk-protein. A quantitative content of 18 free amino acids and 16 bound amino acids has determined in protein-berry and milk-protein concentrates, of which glutamic acid, histidine, methionine, leucine and proline are dominated.

The nonessential amino acids were determined, the content of which is $58.03 \%$ and $56.04 \%$ from the sum of total amino acids in the PBC and MPC (control). The content of essential amino acids in protein-berry concentrate has increased by $14.75 \%$ and the nonessential amino acids by $24.45 \%$ by the following amino acids: threonine at $0.156 \mathrm{mg} \%$, lysine at $0.21 \mathrm{mg} \%$, tryptophan at $0.221 \mathrm{mg} \%$, phenylalanine at $0.525 \mathrm{mg} \%$ compared with the control sample.

Conclusions. The protein-berry concentrates had a polyphenolic compound content of $331.86 \mathrm{mg} / 100 \mathrm{~g}$, which characterizes their natural violet color. The amino acid composition in $\mathrm{PBC}$ has increased by $20.18 \%$ compared with the classic milk-protein concentrate, as a result of complex coagulation of casein and whey proteins. 


\section{Introduction}

Dairy industry needs new approaches and solutions for the processing of milk for products with multifunctional composition. The modern food products have to supply human organism not only with proteins, milk fat and lactose, but also biologically active substances and other essential for normal functioning substances.

The above substances include vitamins, minerals, amino acids, polyphenols and other. The lattest are the most common group of natural antioxidants. They regulate the capillary permeability, strengthen the walls of blood vessels, are synergists of vitamin $C$, and also have the ability to determine the color and taste characteristics of products. By their antioxidant activity, these substances are dominated carotenoids and vitamins $\mathrm{C}$ and $\mathrm{E}$ by ten folds. Polyphenols are contained in vegetables, fruits, berries, and the products of their processing - juices and puree [1-2].

Black currant - one of the most widespread berry crops that grow in Ukraine. Medicinaland-prophylactic properties are determine by fact that the berries contain vitamins, polyphenols, macro- and microelements, polysaccharides including pectin, and others which are necessary for a humans. Berries contain big amount of iron, phosphorus and calcium salts in the form of organic compounds, which are easily digestible by the human body [3].

Black currant berries may be realized in the native state, frozen and in the form of paste. Jam, jelly, syrup, wine etc. are widely used in the food production. Blackcurrant puree is recommended for use as an additional source of biologically active substances.

The development of cheese products technology based on thermo acid coagulation of milk proteins in the presence of functional nutrients is relevant. The source of nutrient can be black currant, which in the form of paste is compliant on the organoleptic level with milk base. In particular thermo acid method of milk processing, which is based on the simultaneous coagulation of milk casein and whey proteins under the influence of acid and high temperature, ensures the formation of a clot with maximum protein content and increased biological value. Amino acids in free and bound states are one of the important organic compounds involved in formation of secondary biosynthesis substances. According to the literature [4], after proteopepsis, proteins form a "free amino acids fund" which can be spent on the formation of new body tissues or on energy. The more of them in the product, the easier they are absorbed by the body. Moreover, free amino acids may experience further metabolic transformations to other low molecular weight compounds that have protective properties [5].

Nutrition and energy value of the homogenized puree LiQberry per $100 \mathrm{~g}$ of the product, not less than: proteins $-1.0 \mathrm{~g}$; carbohydrates $-8.0 \mathrm{~g}$, fiber $-3.0 \mathrm{~g} ; 36.0 \mathrm{kcal} / 150.6 \mathrm{k}$. Physicalchemical indicators of the homogenized black currant puree are given in Table 1 [6].

Table 1

Physical-chemical indicators of the homogenized black currant puree

\begin{tabular}{|c|c|c|c|c|c|}
\hline $\begin{array}{c}\text { Dry soluble } \\
\text { substanses, } \\
\%\end{array}$ & $\begin{array}{c}\text { pH value, } \\
\text { no more } \\
\text { than }\end{array}$ & $\begin{array}{c}\text { Polyphenols, } \\
\text { mg/100 g }\end{array}$ & $\begin{array}{c}\text { Organic } \\
\text { acids, } \\
\text { g/100 g }\end{array}$ & $\begin{array}{c}\text { Vitamin } \\
\mathbf{C} \mathbf{~ m g / 1 0 0} \\
\mathbf{g}\end{array}$ & $\begin{array}{c}\text { Pectins, } \\
\text { g/100 g }\end{array}$ \\
\hline 10.0 & 3.0 & $535-597$ & $2.0-2.5$ & $173-233$ & $0.9-1.1$ \\
\hline
\end{tabular}


In our opinion, the use of blackcurrant paste as a coagulant during thermo acid coagulation of milk proteins is a promising direction of fortification with biologically active substances of milk-protein products and requires additional research.

The aim of this work is determination the content of biologically active substances polyphenolic compounds and amino acid composition in protein-berry concentrates, obtained by thermo acid coagulation of milk proteins using blackcurrant paste as a coagulant.

\section{Materials and methods}

\section{Materials}

Object of research is a protein-berry concentrate (PBC) obtained by thermo acid coagulation of milk proteins using a black currant homogenized paste as a coagulant. This paste was produced in the industrial conditions by advanced technology using hydrodynamic (cavitation) processing of raw materials on a TEK-SM devices, that minimizes the loss of some biologically active substances in raw materials and their biochemical conversion. The berries were treated in the said above setup according to designed regime to a necessary level of homogenization and industrial sterility.

\section{Method of producing protein-berry concentrates}

Berry coagulant was introduced into the milk mixture with $\mathrm{pH}$ of 6.9 in the amount of $7 \%$ with an active acidity of 2.8 . This amount of berry coagulant changes the active acidity in the mixture to provide a balanced isoelectric state of milk proteins in the entire volume at $\mathrm{pH}$ 4.6-4.7 and leads to their active coagulation. Thermal conditioning of the milk mixture and proteins coagulation were realized according to the classical technology with optimization of schedule of thermo acid coagulation $\left(\mathrm{t}=75 \pm 2{ }^{\circ} \mathrm{C}\right.$ duration $\left.2 \pm 1 \mathrm{~min}\right)$ based on the results of previous studies [7]. The thermo acid coagulation allows more complete use of milk proteins and especially whey proteins - the most biologically complete with the contents of essential amino acids.

\section{Performance liquid chromatography method}

Determination of the polyphenolic composition in protein-berry concentrates was carried out by high-performance liquid chromatography using a Promimaence LC-20 Shimadzu liquid chromatographic system (Japan). For the extraction of polyphenols, the weight of the protein-berry concentrate was well mix up and $25 \mathrm{~cm}^{3}$ of isopropyl alcohol were added to $10 \mathrm{~g}$ of PBC. The extraction was carried out in hermetic containers for 5 days at room temperature with occasional mixing. Identification of substances in the studied extracts was determined by comparing the retention time and the spectral characteristics of studied substances with similar characteristics of standards in accordance with the method of polyphenols identification. Chromatography was performed at a wave-length of 225, 255, 286 and $350 \mathrm{~nm}$ [8].

The determination of substances content with established affiliation to specific groups of polyphenols was carried out using standards, the degree of similarity with which was the most, taking into account the chemical form of the substance (aglycone, glycoside). Affiliation of substances in anthocyanins was established with peaks in chromatograms obtained at $530 \mathrm{~nm}$. Identification of glycosides delphinidin, cyanidine, petunidin, peonidin 


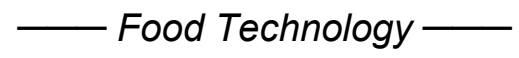

and malvidin was performed by the similarity of time, the content of studied anthocyanins with similar parameters of listed glycosides in Cabernet Sauvignon wine according to the method [9]. Identification of galactoside and arabinosidantocyanins was carried out on the basis of known sequence of glycoside peaks of anthocyanins in black currant berries on chromatograms taking into account the location of glycoside peaks [10]. The content of identified and unidentified anthocyanins was determined by the cyanidine standard. The total content of polyphenols was determined by summing the content of substances, that found in the peak range of flavonoids and phenolic acids in the chromatogram.

Determination of the amino acid composition in protein-berry concentrate was realized by ion-exchange chromatography. The meaning of method is hydrolysis of the sample to the amino acids with the following their identification by method of highperformance liquid chromatography on the amino acid analyzer LC 3000 of the company «Eppendorf-Biotronic» (Germany). Hydrolysis of the sample was realized with a solution of $6 \mathrm{~N}$ hydrochloric acid, at a temperature $(120 \pm 2){ }^{\circ} \mathrm{C}$ for 24 hours. This method allows to determine with accuracy to $\pm(5-10) \%$ the presence of up to 18 amino acids with a minimum level of their content in solution $(0,500 \pm 0,006) \mu \mathrm{mol} / \mathrm{ml}$. Quantitative evaluation of the content of individual amino acids was realized comparing the peak areas on the aminograms calculated using the Winpeak integration systems of the company "Eppendorf-Biotronic" (Germany) to a similar level, with peak areas obtained by analyzing a standard mixture of amino acids containing $2.5 \mu \mathrm{mol}$ each amino acids in $1 \mathrm{~cm}^{3}$ of standard solution.

The amino acid content in the protein-berry concentrate was compared with their content in the control sample - the milk-protein concentrate (MPC) obtained according to the classical technology $\left(\mathrm{t}=90 \pm 2{ }^{\circ} \mathrm{C}\right.$ during $\left.5 \mathrm{~min}\right)$, using an acid whey with titrated acidity 160 $180^{\circ} \mathrm{T}$ as a coagulant, in the amount of $10 \%$ from the mass of milk.

\section{Results and discussion}

At the first stage of research, the transition degree of polyphenol composition, including anthocyanins, into protein-berry concentrates was determined, taking into account their content in blackcurrant paste. Black currant anthocyanin complex is determined by a set of main components: 3 glycosides and 3-rutinoside delphinidin and cyanidin, which is unchanged for fruits of all varieties with black color [11]. Dye-ware colors of berry raw materials are low molecular weight phenolic compounds, that refer to bioflavonoids, in particular anthocyanins, which in plants are in the form of glycosides. In addition, the berries contain flavones, flavonols, catechins, hydroxy-cinnamic acids, which led to the natural purple color of protein-berry concentrates. In order to determine the transition degree of biologically active substances, the polyphenolic composition in blackcurrant paste, proteinberry concentrate and colored whey were analyzed. The chromatogram of the alcoholic extract of protein-berry concentrate is shown in Figure.1. 


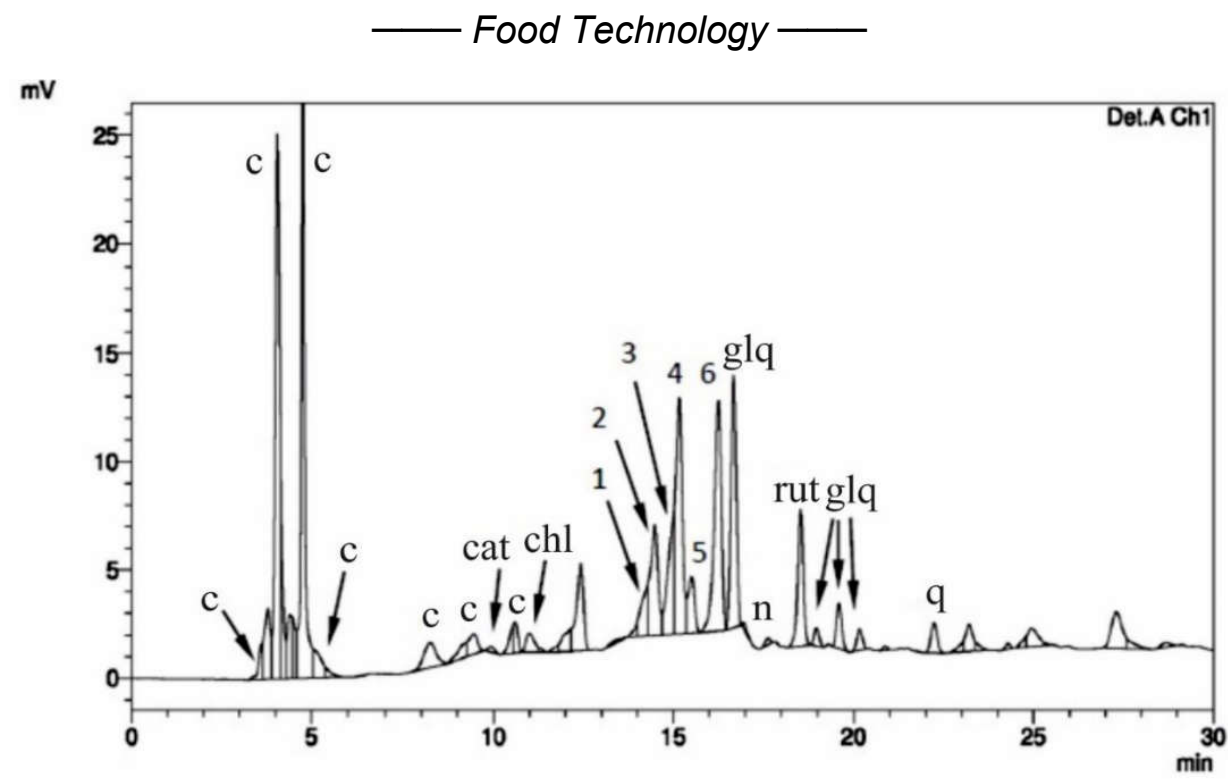

Figure 1. Chromatogram of the alcoholic extract of protein-berry concentrate at $255 \mathbf{n m}$ : $\mathrm{c}$ - catechins, cat - catechin, chl - chlorogenic acid, $\mathrm{n}$ - naringin, rut - rutin, glq - quercetin glycosides, q - quercetin,

1 - delphinidin-galactoside, 2 - delphinidin-glucoside, 3 - cyanidin-galactoside, 4 - delphinide-arabinoside, 5 - cyanidin-glucoside,

6 - petunidine-galactoside + cyanidine-arabinoside + petunidine-glucoside + peonidin-galactoside .

The polyphenolic composition of protein-berry concentrate is presented in Table 2 correlated with the composition of a specially-processed blackcurrant paste (control) [6].

Polyphenolic composition of protein-berry concentrate

Table 2

\begin{tabular}{|c|c|c|c|}
\hline Polyphenol group & $\begin{array}{c}\text { Content, } \\
\mathbf{m g} / \mathbf{1 0 0}\end{array}$ & Individual substances & $\begin{array}{c}\text { Content, } \\
\mathbf{m g} / \mathbf{~ 1 0 0} \mathbf{g}\end{array}$ \\
\hline Phenolic acids & 0.18 & Chlorogenic acid & 0.18 \\
\hline Catechins & 57.65 & Catechin & 4.83 \\
\hline \multirow{2}{*}{ Flavonols } & 34.10 & Rutin & 24.00 \\
\hline Flavanones & 38.38 & Quercetine & 1.10 \\
\hline \multirow{4}{*}{ Anthocyanins } & \multirow{3}{*}{187.02} & Naringin & 1.50 \\
\cline { 3 - 4 } & & Delphinidin-3-O-galactoside & 15.70 \\
\cline { 3 - 4 } & & Delphinidin-3-O-glucoside & 26.35 \\
\cline { 3 - 4 } & & Cyanidin-3-O-galactoside & 19.83 \\
\cline { 3 - 4 } & & Delphinidin-3-O-arabinoside & 45.48 \\
\cline { 3 - 4 } & & $\begin{array}{c}\text { Cyanidin-3-O-glucoside } \\
\text { + Pet-gluc + Cyan-arab + }\end{array}$ & 13.48 \\
\cline { 3 - 4 } & & Peon-gluc + Mal-gal & 54.30 \\
\hline Unidentified & 14.53 & Peon-arab + Mal-gluc & 0.30 \\
\hline $\begin{array}{c}\text { Amount of } \\
\text { polyphenols }\end{array}$ & \multirow{2}{*}{331.86} & Malvidin-3-O-arabinoside & 0.65 \\
\hline
\end{tabular}


The content of polyphenolic substances in the obtained protein-berry concentrates is $331.86 \mathrm{mg} / 100 \mathrm{~g}$. For comparison, the content of polyphenols in blackcurrant paste ranged from 535 to $597 \mathrm{mg} / 100 \mathrm{~g}$. Probably, PBC are full-fledged ingredients for use in recipes of cheese products for health purposes, which have antioxidant, tonic effect.

About $55.31 \%$ of polyphenolic compounds, including anthocyanins, stay in proteinberry concentrates. The transition degree of polyphenolic compounds into the colored whey is $34.47 \%$ of their total amount. This fact is caused by the fact that anthocyanins are sensitive to temperature regimes of milk protein coagulation, which leads to their destruction.

At the next stage, the amino acid composition of protein-berry and milk-protein concentrates (control) was investigated and it has shown that the protein fractions contain a full set of amino acids, including essential, - this confirms their high biological value.

In protein-berry and milk-protein concentrates the free and bound amino acids content, including essential (EAA) and nonessential (NEAA), was calculated and shown in Figures 3 and 4 , respectively.
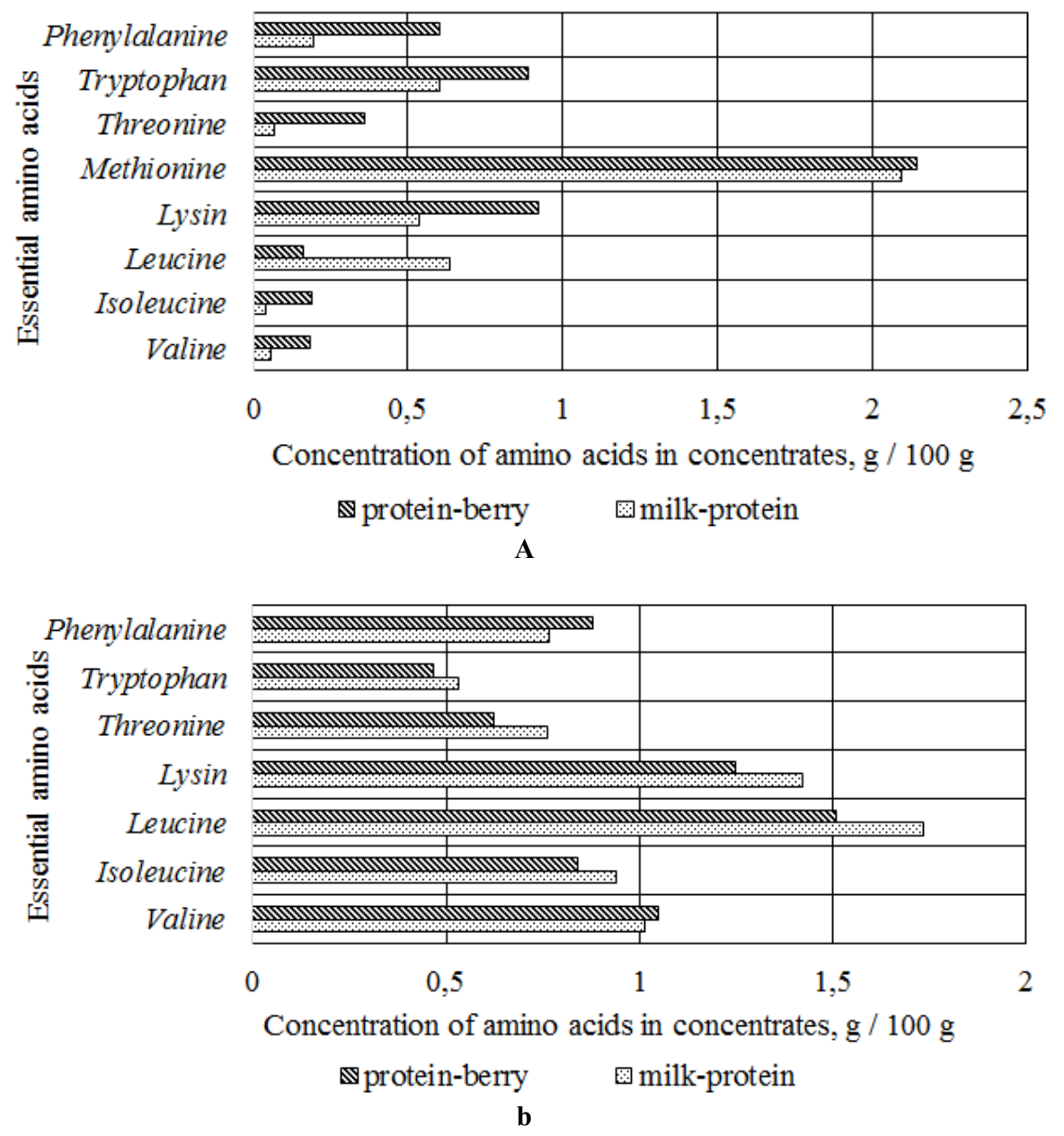

Figure 3. The content of free (a) and bound (b) essential amino acids in protein-berry and milkprotein concentrates $(n=3, p \leq 0.05)$ 


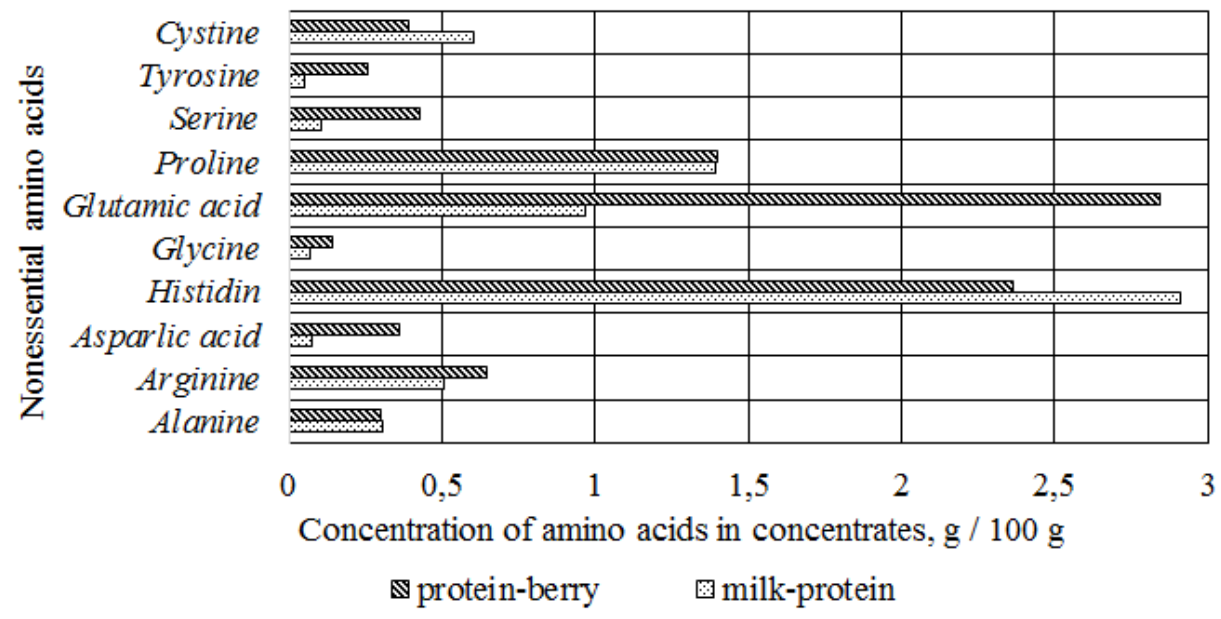

a)

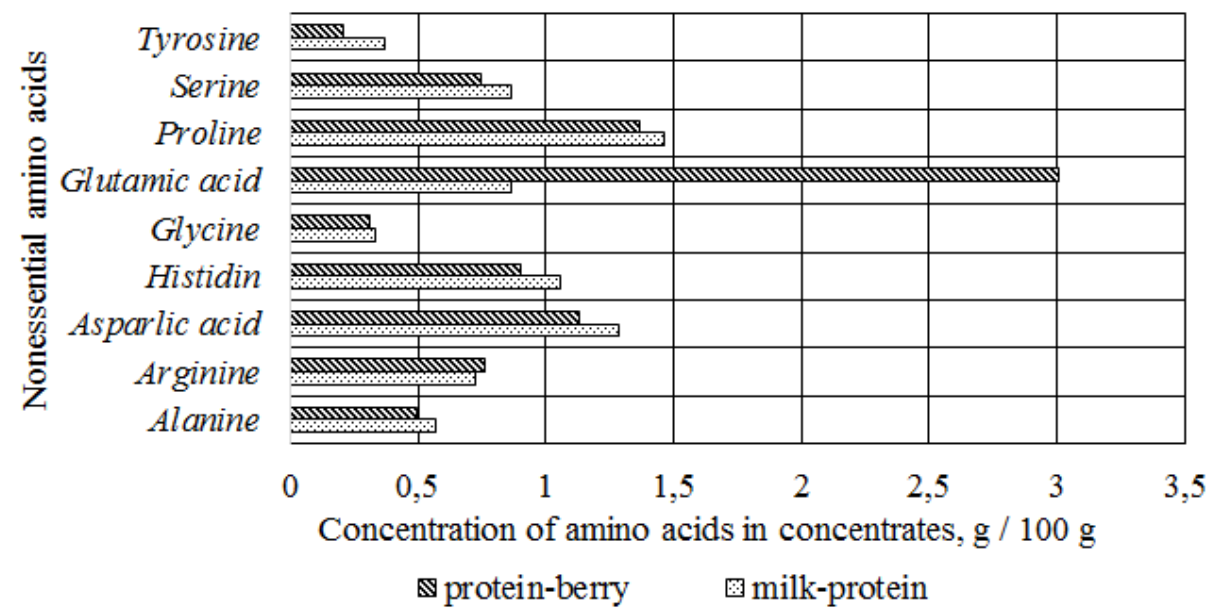

b)

Figure 4. The content of free (a) and bound (b) nonessential amino acids in protein-berry and milk-protein concentrates $(n=3, p \leq 0.05)$

According to the results (Figures 3 and 4), the total amino acids content in PBC increased by $20,18 \%$ compared with the control. This is characterized by an increase in the transition degree of casein and the maximum amount of whey proteins in the concentrate, as a result of organic blackcurrant paste action during thermo acid processing.

The maximum amount of glutamic acid in all samples was recorded. 18 free amino acids, among which histidine and methionine predominate, and 16 bound amino acids (leucine and proline prevail) were identified in concentrates. All essential amino acids are identified in the PBC and MPC. Their importance is due to the fact that they are not synthesized by the body, and the deficiency affects the protein regeneration. The content of the above amino acids from the total amount is $41,97 \%$ and $43,96 \%$, respectively. 


\section{— Food Technology -}

In addition, glutamic acid in a bound state accumulates in large quantities in proteinberry concentrates at the level of 3,007 / $100 \mathrm{~g}$, due to its high content in black currant $(34,7$ $\mathrm{g} / 100 \mathrm{~g}$, of which $33.2 \mathrm{~g} / 100 \mathrm{~g}$ in a bound state [12]). The above amino acid plays an important role in nitrogen metabolism, supports respiration of brain cells and performs the function of a neurotransmitter in the human body [13]. Leucine prevails in the milk-protein concentrare $(1.732 \mathrm{~g} / 100 \mathrm{~g})$, methionine and cystine were not detected in all samples. In the free state, histidine which is involved in the formation of proteins and affects metabolic reactions, is present in large quantities (2.362 and $2.909 \mathrm{~g} / 100 \mathrm{~g}$, respectively) in concentrates.

Nonessential amino acids are performed important functions in the body - glucose synthesis (alanine), take part in enzymatic processes (arginine), improve the skin structure (proline), and some of them (cystine, tyrosine, glutamic acid) play a physiological role, no less than essential amino acids [14]. Glutamic acid, proline and histidine are dominant in concentrates, among essential amino acids that perform the functions of precursors in the protein synthesis and other biologically active compounds. According to the results (Figure 4 ), the content of NEAA from the amount of total amino acids in the PBC and MPC is $58.03 \%$ and $56.04 \%$, respectively.

Analyzing the results, we can say about the increase in the amount of EAA in the proteinberry concentrate by $14.75 \%$ and NEAA by $24.45 \%$ in the following amino acids: threonine by $0.156 \mathrm{~g} \%$, lysine by $0.21 \mathrm{~g} \%$, tryptophan by $0.221 \mathrm{~g} \%$, phenylalanine $-0.525 \mathrm{~g} \%$ compared with the control sample.

Important is the fact that the protein-berry concentrate contains $50.06 \%$ of amino acids in the free state, including the content of essential amino acids is $41.44 \%$. The resulting patterns indicate that the protein-berry concentrate has a more easily digested form than the classical concentrate obtained by thermo acid coagulation of milk proteins by acid whey.

\section{Conclusion}

The resulting thermo acid coagulation of milk proteins, $\mathrm{PBC}$ are characterized by a content of polyphenolic compounds at the level of $331.86 \mathrm{mg} / 100 \mathrm{~g}$ and amino acids -31.14 $\mathrm{g} / 100 \mathrm{~g}$. This has a positive effect on the biological value of products based on them and organoleptic characteristics. As a result, protein-berry concentrates were characterized by the presence of violet color, that characteristic for raw materials containing anthocyanins. The use of colored PBC as a basis for cheese products will ensure the exclusion of food colors and flavors of artificial origin, and also will prolong their storage life.

\section{References}

1. Rasouli H., Khodarahmi R., Farzaei M. (2017), Polyphenols and their benefits: A review, International Journal of Food Properties, doi: 10.1080/10942912.2017.1354017.

2. Tian Y., Liimatainen J., Alanne A.-L., and others (2017), Phenolic compounds extracted by acidic aqueous ethanol from berries and leaves of different berry plants. Food Chem., 220, pp. 266-281. doi: 10.1016/j.foodchem.2016.09.145.

3. Makarkina M. A., Yanchuk T. V. (2010), The characteristics of the black currant grades by sugars and organic acids content, Modern gardening, 2, pp. 9-12.

4. Hubskyi Yu. I. (2007), Bioorhanichna khimiia, Vinnytsia. 


\section{— Food Technology -}

5. Kobyletska M.S., Terek O.I. (2012), Effect of salicylic acid on free amino acids content in wheat Triticum aestivum L. and sunflower Helianthus annuus L. under the actions of cadmium ions, Studia Biologica, 6(1), pp. 87-92.

6. Bessarab O. S., Osipenko S. B., Stoianova L. O., Pakhomova K. Yu. (2014), Innovatsiina tekhnolohiia fruktovykh homohenizovanykh produktiv pidvyshchenoi biolohichnoi tsinnosti na osnovi hidrodynamichnoi obrobky syrovyny, Obladnannia ta tekhnolohii kharchovykh vyrobnytstv, 32, pp. 7-19.

7. Grek O., Onopriichuk O., Pshenychna T. (2017), The rationalization of the parameters of milk proteins' thermo acid coagulation by berry coagulants, Food and Environment Safety, 7(1), pp. 47-53.

8. Hodakov I. V., Makarenko O. A. (2010), Vyisokoeffektivnaya zhidkostnaya hromatografiya $\mathrm{v}$ issledovanii rastitelnyih polifenolov. Vesnik stomatologii, 5, pp. 5960 .

9. Hodakov I. V. (2014), Primenenie vina Kaberne-Sovinon dlya opredeleniya identifikatsionnyih harakteristik 3-O-glyukozidov antotsianidinov pri analize sostava antotsianov v paste iz yagod cherniki. Himiya rastitelnogo syirya, 2, pp. 147-154.

10. Burdulis D., Ivanauskas L., Dirse, and others (2007), Study of diversity of anthocyanin composition in bilberry (Vaccinium myrtillus L.) fruits. Medicina (Kaunas), 12, pp. 971-977.

11. Petrova S. N., Kuznetsova A. A. (2014), Sostav plodov i listev smorodinyi chernoy. Himiya rastitelnogo syirya, 4, pp. 43-50.

12. Simakhina G. A., Naumenko N. V. (2007), Perspektivy kompleksnogo ispolzovaniia chernoi smorodiny dlia polucheniia krioproduktov, 4, pp.72-74.

13. Redde M.K. Amino acid. Chemical compound, Available at: http://www.britannica.com.

14. Takahashi T., Toda E., Singh B. (2011), Essential and non-essential amino acids in relation to glutamate, The Open Nutraceuticals Journal, 4, pp. 205-212. 